\title{
凝集構造制御による $\mathrm{TiN} / \mathrm{Si}_{3} \mathrm{~N}_{4}$ 焼結体の機械，電気特性の最適化
}

\author{
秋宗淑雄・宗像文男・安藤元英・岡本祐介・広崎尚登* \\ 日産自動車(株)材料研究所, 237 横須賀市夏島町 1
}

\author{
Optimization of Mechanical and Electrical Properties of TiN/ $\mathrm{Si}_{3} \mathrm{~N}_{4}$ \\ Material by Agglomerates-Microstructure-Control
}

Yoshio AKIMUNE, Fumio MUNAKATA, Motohide ANDO, Yusuke OKAMOTO and Naoto HIROSAKI*

Materials Research Laboratory, Nissan Motor Co., Ltd., 1, Natsushima-cho, Yokosuka-shi, Kanagawa 237

\begin{abstract}
Microstructure of $\mathrm{TiN} / \mathrm{Si}_{3} \mathrm{~N}_{4}$ ceramics was tailored by using a cosintering process of their agglomerates, then structure-properties relations were examined by measuring mechanical property and electrical conductivity of TiN/ $\mathrm{Si}_{3} \mathrm{~N}_{4}$. The TiN/ $\mathrm{Si}_{3} \mathrm{~N}_{4}$ material using TiN and $\mathrm{Si}_{3} \mathrm{~N}_{4}$ agglomerates showed duplex microstructure. This materials showed a sudden onset of electrical conduction at a lower TiN content than that of conventional composites. The duplex materials exhibited a higher fracture toughness than that of the normal composites, while other hand its strength remained at the same level of TiN. It is concluded that higher fracture toughness of duplex materials resulted from the complex fracture path at the interface between $\mathrm{Si}_{3} \mathrm{~N}_{4}$ and TiN agglomerates.

[Received April 1, 1996; Accepted October 8, 1996]
\end{abstract}

Key-words : $\mathrm{Si}_{3} \mathrm{~N}_{4}$, TiN, Duplex microstructure, Agglomerate, Electrical resistivity

\section{1. はじめに}

軽量で高強度なセラミックスの利用を拡大するためには，価 格を低減させるとともに，セラミックスを部品に用いることで 機械類の性能を飛躍的に向上させることが必要である。価格低 減の方法の一つには，加工技術適用の幅を持たせることも重要 であり，例えば放電加工ができるような電気伝導性を付与した 素材とすることも必要である. そのため機械特性の高い窒化ケ イ素に電気伝導性を付与する新材料の製造技術の研究が鋭意行 われている1) 6).

一方, セラミックスの微構造を制御し高度な機械特性を得る

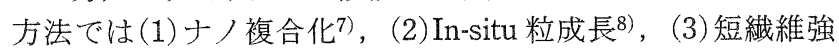

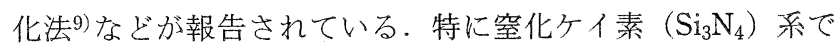
は (2)の In-situ 粒成長 ${ }^{8)}$ による機械強度の向上を利用する製造 方法が有効上考えられる. なたべース材料に第 2 相を添加す るには各相の焼結速度を合わせることが重要であり, 各相のグ リーン体密度を調節し Duplex-Bimodal 構造を付与する組織制 御方法が実用上有力な手法であると報告されている10).

$\mathrm{Si}_{3} \mathrm{~N}_{4}$ の強度を維持しつつ電気伝導機能を付与するには, 絶 縁材料である $\mathrm{Si}_{3} \mathrm{~N}_{4}$ に導電材料である窒化チタン ( TiN) など の粒子を分散させる方法1) 5) や, $\mathrm{Si}_{3} \mathrm{~N}_{4}$ 粒子の表面を導電性粒 子でコートし焼結する方法6)が知られている. 前者で用いられ ているプロセスでは原料のマトリックス粉末に第 2 相の粉末 を複合化した後，焼結する方法であるが，このような方法では TiN を $30 \mathrm{vol} \%$ 加 $40 \mathrm{vol} \%$ 程度上比較的多量に添加する必 要があり, そのため比重が増加するため軽量という窒化ケイ素 の良い特性が生かされなくなっている。 また, 後者では工程が 複雑になり高コストになると考えられる。

そこで本研究では, 従来は凝集体として排除されている粗大 顆粒を微構造の創製に活用するプロセス技術を用い，高強度 $\mathrm{Si}_{3} \mathrm{~N}_{4}$ にTiN を顆粒として添加し同時焼結させる方法をとるこ とで, 少量の添加で機能を発現させる凝集体を分散させた微構 造を構築していく. 同時に本材料の機械強度の評価と電気伝導 機構の解析を行った.

\section{2. 実験方法}

\section{1 原料及び試験片の組成}

マトリックスとしては市販の $\mathrm{Si}_{3} \mathrm{~N}_{4}$ 粉末（宇部興産製， $\mathrm{E} 10$, 平均粒子径 $0.6 \mu \mathrm{m}$ ) に焼結助剂（信越化学工業製, 酸化 イットリウム $\left(\mathrm{Y}_{2} \mathrm{O}_{3}\right) 10$ mass\%, アルコア製アルミナ $\left(\mathrm{Al}_{2} \mathrm{O}_{3}\right) 5$ mass\%）を添加し，ボールミルを用いて，24h アルコール中 で粉砕混合後乾燥し顆粒とした。添加相には市販のTiN 粉末 （新日本金属化学製 $\mathrm{TiN}$, 平均粒子径 $3 \mu \mathrm{m}$ ) に焼結助剂とし て前記 $\mathrm{Y}_{2} \mathrm{O}_{3}$ 孝 5 mass\%加えてボールミルで24h アルコール中 で粉砕混合後乾燥し顆粒とした. $\mathrm{Si}_{3} \mathrm{~N}_{4}$ 顆粒及び $\mathrm{TiN}$ 顆粒を $250 \mu \mathrm{m}$ 以下にふるい分けし, 所定の体積比に秤量しV-ブレン ダーで混合後「凝集体混合粉末」とした，比較材としては上述 の $\mathrm{Si}_{3} \mathrm{~N}_{4}$ 粉末及び TiN 粉末を所定の体積比になるように混合

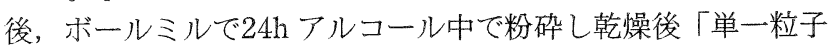
混合粉末」とした。

\section{2 焼結条件と試験片形状}

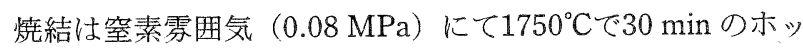
トプレス焼結を行った。な抢形状は $40 \times 50 \times 5 \mathrm{~mm}$ であり, 加 圧力は $20 \mathrm{MPa}$ であった。前記形状の平板より JIS 形状の試験 片を作製した。

\section{3 微構造観察と特性評価}

粒子群微構造についての評価は試料をダイヤモンド粒子 $(0.25 \mu \mathrm{m})$ で研磨した後, 光学顕微鏡亡走査型電子顕微鏡 (SEM) 及び電子線プローブマイクロアナライザー (EPMA) にて行った。強度試験は JIS による 4 点曲げ試験方法を用い, 破壊勒性試験は JIS による SEPB 万法を用いて破壊勒性值を 求めた。ここで, 曲げ試験の破壊方向はホットプレス軸に平行 であり，勒性試験の破壊方向はホットプレス軸に垂直方向であ る. 電気伝導度は体積抵抗率（JIS H0505） として $3 \times 4 \times 40$ $\mathrm{mm}$ の JIS 曲げ試験片を用いてホットプレス軸に直角方向の抵 抗值の逆数として求めた.

\section{1 凝集構造制御材料の微構造}

\section{3. 実験結果と考察}

図 $1 \mathrm{~A} \sim \mathrm{C}$ に「凝集構造制御材料」の微構造の光学顕微鏡写 

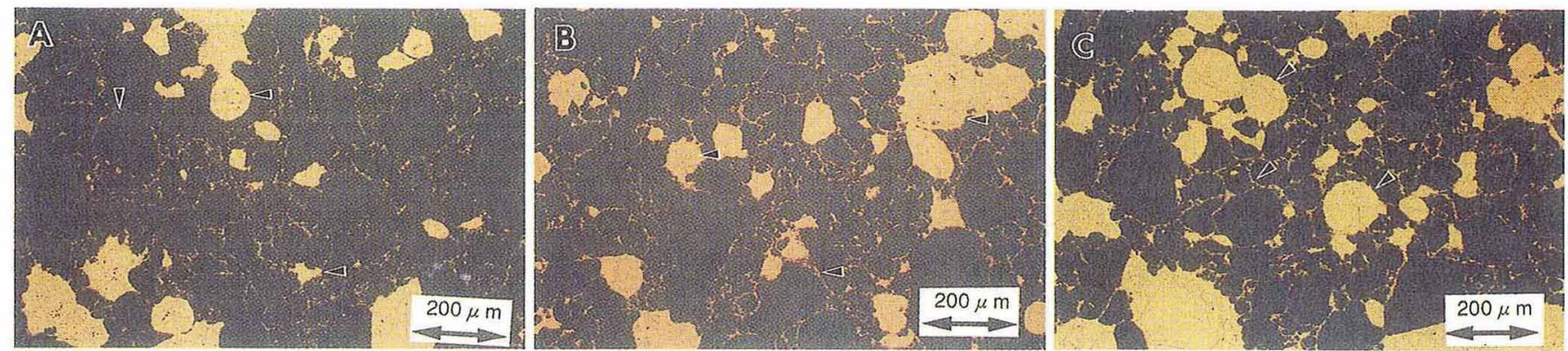

Fig. 1. Optical micrograph of agglomerates-microstructure-controlled microstructure.

((A) $\mathrm{TiN}=13.3 \mathrm{vol} \%$, (B) $\mathrm{TiN}=20.9 \mathrm{vol} \%$, (C) $\mathrm{TiN}=29.1 \mathrm{vol} \%$, Arrow : TiN)

真を, 図 2 に「単一粒子混合材料」の光学顕微鏡写真大示した。 図 $1 \mathrm{~A}$ の微構造は TiN 顆粒が $13.3 \mathrm{vol} \%$ 含有した構造であり直 径 $100 \mu \mathrm{m}$ から $500 \mu \mathrm{m}$ の $\mathrm{Si}_{3} \mathrm{~N}_{4}$ 顆粒と TiN 顆粒を接続する直 径数十 $\mu \mathrm{m}$ の小 TiN 顆粒と TiN 単一粒子からなるネットワー

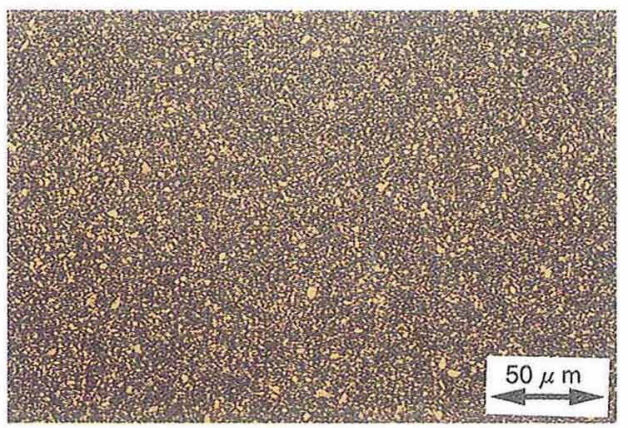

Fig. 2. Optical micrograph of composite microstructure. $(\mathrm{TiN}=29.1 \mathrm{vol} \%)$
ク（TiN ネットワーク）が構築されている，同様に，図 $1 \mathrm{~B} は$ 20.9 vol\%の場合で岁る。ここでもマトリックスの $\mathrm{Si}_{3} \mathrm{~N}_{4}$ 顆粒 境界にある TiN 顆粒周辺にも数十 $\mu \mathrm{m}$ の TiN 単一粒子もしく は顆粒が分散し，マトリック久の $\mathrm{Si}_{3} \mathrm{~N}_{4}$ 顆粒と TiN 顆粒及び $\mathrm{Si}_{3} \mathrm{~N}_{4}$ 顆粒周囲に薄い TiN ネットワークが配合された微構造と なっていることが確認され，TiN 粒子が連結されていると推 測さ机る。図 1C \&同様に29.1 vol\%の場合で岁り，TiNの ネットワークがより多く形成されている。図 2 では29.1 vol\% の単一粒子混合材料の場合であり, TiN 粒子が単独もしくは 複数個が連結状態で分散していると推测されるが，光学顕微鏡 だけでは組織の特定は困蜼である。

そこで，EPMAにより $20.9 \mathrm{vol} \%$ の「凝集構造制御材料」の Si と Ti の元素分析を行い, 顆粒構成元素の存在位置の確認を 行った（図 3 ）。ここでも，TiN 顆粒が連結された様子が確認 でき, 光学顕微鏡観察の結果々併世て前述の TiN 顆粒をふく む TiN ネットワークによる連結微構造組織が形成されている. 一方の「単一粒子混合材料」では, 粒子間の連結を確認するに
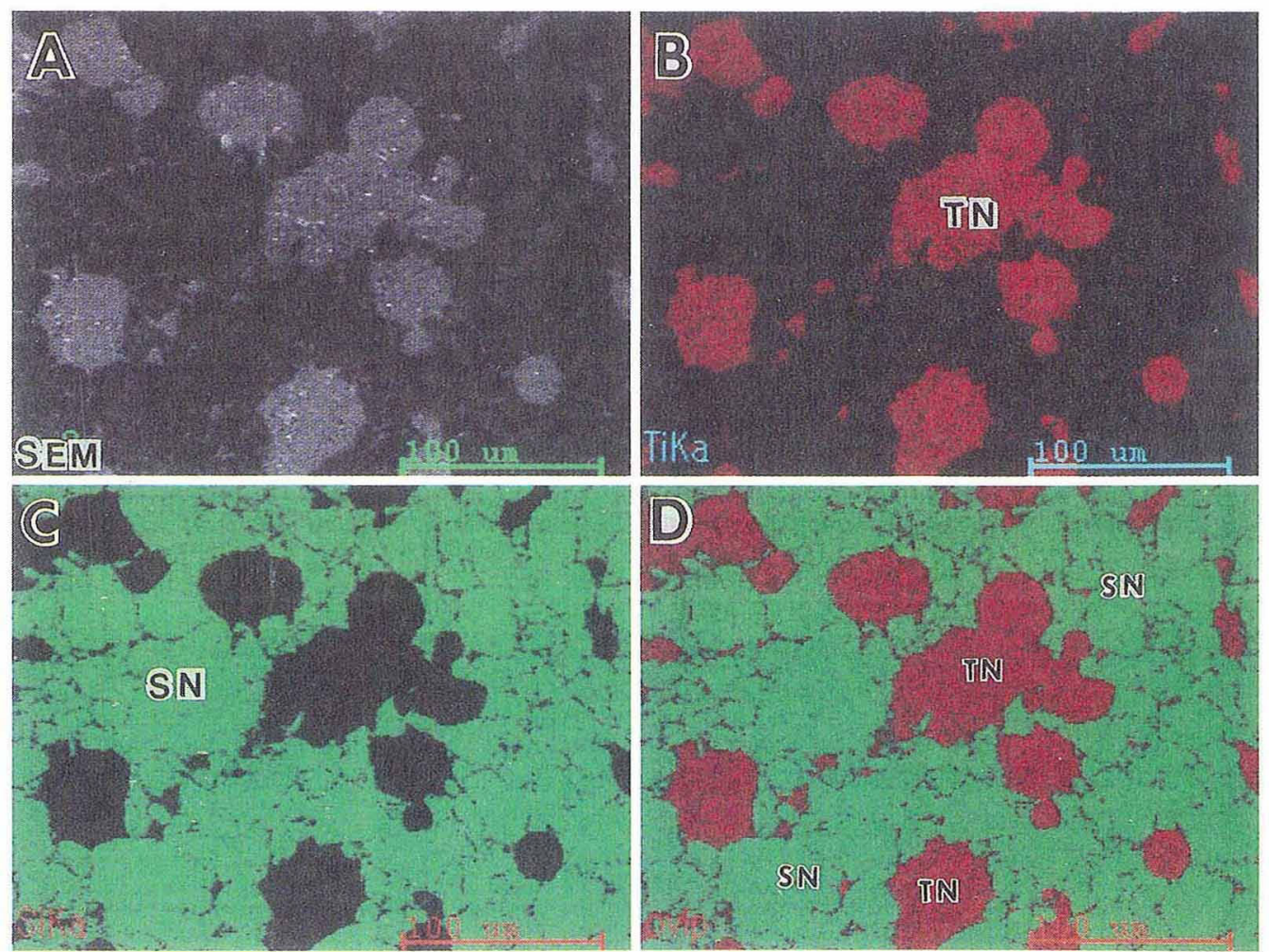

Fig. 3. Elements annalysis of agglomerates-microstructure-controlled materials by EPMA (TiN=20.9 vol\%). (A : SEM, B : Ti element, C : Si element, D : Ti and Si composed photograph) 


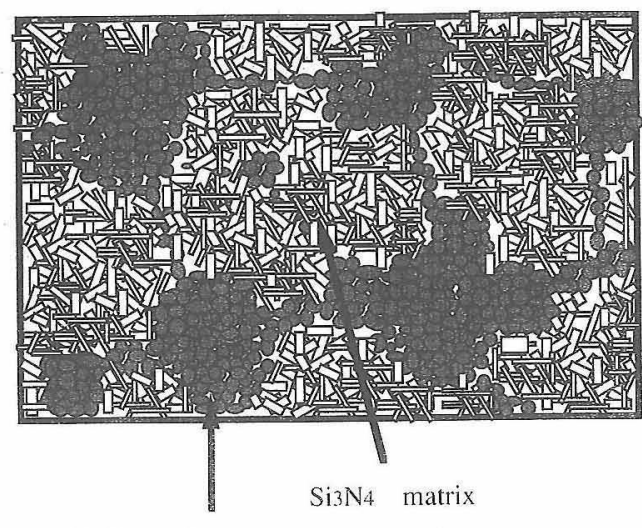

TiN agglomerate

Fig. 4. Schematic of the microstructure of agglomerates-microstructure-controlled material.

はいたらず，電気抵抗率の測定による確諗が必要である. 結晶 相構成をX 線回折で多ると, 主結晶相は $\beta-\mathrm{Si}_{3} \mathrm{~N}_{4}$ と TiN であ り，文献1)に記載の $\mathrm{Y}_{2} \mathrm{TiO}_{5}$ 《確認できなかったので助㓮の酸 化物や酸素壮粒子内に固溶しているか界面に薄いガラス相とし て存在していると考えられる.图4 には上記結果から考えられ る $\mathrm{TiN}_{-} \mathrm{Si}_{3} \mathrm{~N}_{4}$ 系「凝集構造制御材料」の微構造について模式 図で示した.

\section{2 疑集構造制御材料の電気伝導度}

(1) セラミックスの導電理論

紿緣材料に導電材料が混合した材料での電導理論は (1) 実効 媒質理諭11) と(2)パーコレーション理論12) 14)が報告されてい る. 前者では Landauer が報告した理論であり 2 種の尊電率の 異なる物質の混合系の導電率は次の式で表されることが報告さ れている.

$$
\begin{aligned}
\sigma_{\mathrm{m}}= & {\left[\left(3 X_{1}-1\right) \sigma_{1}+\left(3 X_{2}-1\right) \sigma_{2}+\left[\left\{\left(3 X_{1}-1\right) \sigma_{1}\right.\right.\right.} \\
& \left.\left.\left.+\left(3 X_{2}-1\right) \sigma_{2}\right\}^{2}+8 \sigma_{1} \sigma_{2}\right]^{1 / 2}\right] / 4
\end{aligned}
$$

ここで， $\sigma_{\mathrm{m}}$ は複合材料の導電率， $\sigma_{1}$ はマトリックスの導電 率， $\sigma_{2}$ は添加粒子の導電率， $X_{1}$ はマトリックスの体積率， $X_{2}$ は添加粒子の体猜率である。

(2)のパーコレーション理論では導電粒子がマトリックス中 で接続したときに電気が流れるとした考え方で，多くのモデル

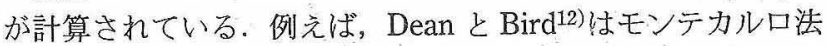
による数值計算で，同一粒径の 3 次元のサイトパーコレー ションの場合の導通の得られる臨界体積率 $\left(V_{\mathrm{c}}\right)$ は単純立方 (SC) で 0.312 , 体心立方 (BCC) で 0.248 , 面心立方 (FCC) で 0.200 となることを報告した。一方, Shante と Kirkpatrick ${ }^{13)}$ は self-avoiding walk の概念を導入し単純立方の場合の臨界体 積を0.29であると報告している.Kirkpatrick ${ }^{14)}$ は 3 種のモデ ル $(1:$ bond percolation, $2:$ site percolation, $3:$ correlated bond percolation) についてモンテカルロ法による数值計算で $V_{\mathrm{c}}$ を求め, 3 次元の bond percolation で単純立方の場合の臨 界体積を 0.25 で出ると報告した. Malliaris と Turner ${ }^{15}$ はポリ マーに金属粒子を添加する実験的手法で添加系の粒子の直径が 異なる場合に臨界体積率が变化することも報告しており, 微構 造モデルに大きく依存することを示している。

(2) 凝集構造制御材料の電気伝導度

電気抵抗を測定した結果を図 5 に示した。測定結果は JIS に よる二端子法のため絶対值では精度の限界があるものの，相対 值の比較は可能であると考えられる。すず，「凝集構造制御材 料」では 20.9 vol\%で抵抗率が大きく低下し導通が起きている

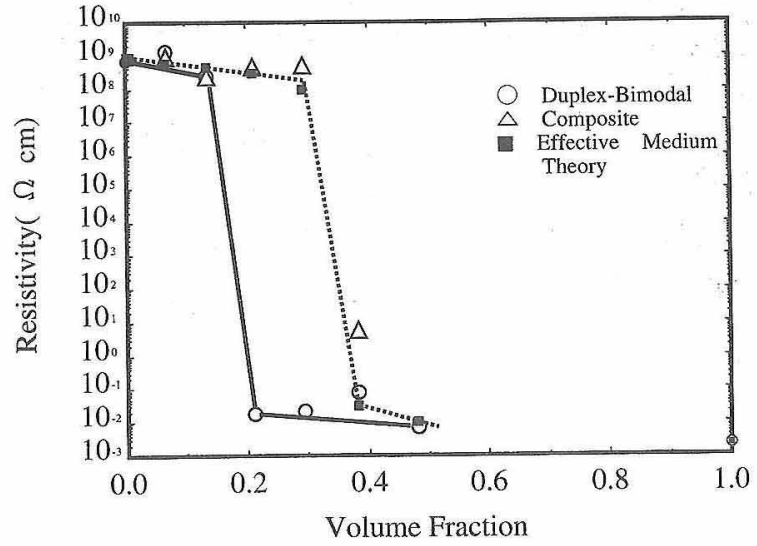

Fig. 5. Electrical resistivities of two types of materials and theoretical value.

ことが確認された。単一粒子混合材料」では 38 vol\%で抵抗 值が低下するため $38 \mathrm{vol} \%$ 以上では，接触している TiN 粒子 が增加していると考えられる。実效媒質理論による値を(1)式 で計算し併記したが「単一粒子混合材料」ではその結果とほぼ 一致するため前記抵抗值变化を説明できると考えられる。

一方の「凝集構造制御材料」については, Dean と Bird ${ }^{12)}$ に よるパーコレーションの臨界点 $\left(V_{\mathrm{c}}=0.209\right)$ とすると FCC もしくは SC 充填の場合のパーコレーションの結果と良く一致 するため TiN 顆粒が FCCもしくは SCに充買して接触したも のと考えられるが, 因 1 の微構造からは顆粒粒界にTiN 微小 顆粒が偏析し網目状の TiNネットワークが形成されたために TiN 粒子の接触が起き， $V_{\mathrm{c}}$ が小さくなったものと考えられる。 図1 と図 3 に示した微構造形態からは後者であり,このモデ ルで現象をよく説明できる.このような粒度分布を持った顆粒 が粗大な紿緣体顆粒粒界に配置しネットワークを形成すること によるパーコレーションモデルを検討していく必要が䒛る。

この結果からは添加粒子の粒径により抵抗率が变化すること を意味して㧍り，単一粒子の複合化11)でなくても粒子形状や サイズを制御した粒子集合体であれば導電機能に貢献できるこ とを示したものである。

\section{3 凝集構造制御材料の機械的特性}

曲げ强度を図 6 に示した。強度は「単一粒子混合材料」では 20.9 vol\%で1100 MPaでありマトリックスの1000 MPa と比 べて複合化効果が現机て㧍り, 文献記載の強度における增加傾 向1),2) を示している。一方の「㠜集構造制御材料」では6.6

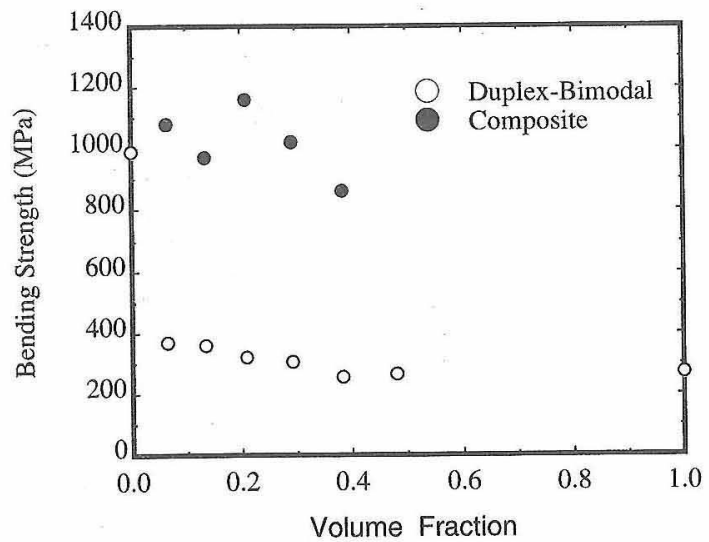

Fig. 6. Bending strength of two types of materials. 
vol\%以上の添加で350 MPa 程度で，TiN 単独の焼結体の強度 水準と同じであり TiN 顆粒もしくは TiN と $\mathrm{Si}_{3} \mathrm{~N}_{4}$ 界面が破壞 起点となっていると推定される，見掛けの破壞勒性値（図 7) は逆の結果で物り，「単一粒子混合材料」ではマトリックスの $5.8 \mathrm{MPa} \sqrt{\mathrm{m}}$ 加ら若干增加を示して抢り，文献1)記載の傾向を 示した，一方，「凝集構造制御材料」では TiN 顆粒が38 vol\% 添加材料で9.3 MPa $\sqrt{\mathrm{m}}$ を示し高勒化素材となっているので凝 集構造制御焼結体による破㯖経路が極めて複雑になり高勒性と なっていることが予測される。

SEPB 法による破壊勒性测定後の試験片について破壊面の SEM 観察を行った。その結果は図 8A〜Cに示したと抢りで

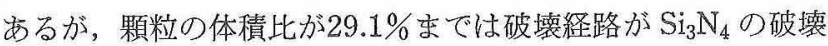
経路に依存して抢り破面が $\mathrm{Si}_{3} \mathrm{~N}_{4}$ 単独の場合よりクラックの偏 向がみられるむのの（図 $8 \mathrm{~A}$ )，相対的にフラットで䩗性值の 増加もわずかである。一方，顆粒比が38 vol\%では破裳経路が $\mathrm{Si}_{3} \mathrm{~N}_{4}$ 顆粒間となり数百 $\mu \mathrm{m}$ の周期でマクロな偏向を起こして いることが確認された（図 $8 \mathrm{~B}$ ). $\mathrm{Si}_{3} \mathrm{~N}_{4}$ 顆粒とTiN 顆粒の界面 は強固に接合されていると予想されるので，破壞靯性值への奇 与度は TiN 顆粒 $-\mathrm{Si}_{3} \mathrm{~N}_{4}$ 顆粒界面の熱膨張率差による残留応力 に起因するマクロなクラックディフレクション機構16) と個々 の粒子周囲で発生するミクロなグレインブリッジング機 構 ${ }^{17)}$-20) 方同時に作用している（図 8C）上推定される。

本実験で用いたSEPB 法を適用した場合には初期亀裂と顆 粒径の大小が重要となり, 添加顆粒が大きな顆粒（数百 $\mu \mathrm{m}$ ） として働くか又は個々の粒子（数 $\mu \mathrm{m} ）$ として働くかが勒性値 の大小を決めるものである。したがって，SEPB法による破懐 勒性值の測定だけでは破壊機構を考えるには不十分で，このよ うな Duplex 微構造を有する材料については，Rカーブの測定 による詳細な機械特性評価が必要であり，今後の研究課題であ る。

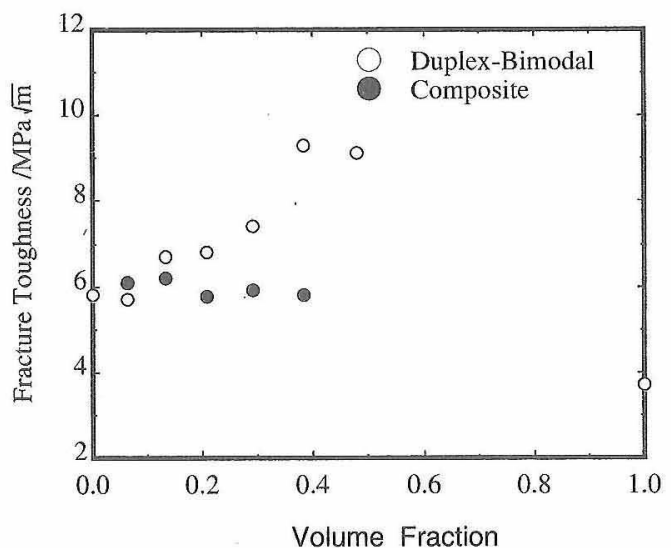

Fig. 7. Fracture toughness by SEPB method of two types of materials.

\section{4. まとめ}

本研究の結果をまとめると，次のように整理される，

(1) $\mathrm{Si}_{3} \mathrm{~N}_{4}$ にTiN 球状顆粒を混合した「凝集構造制御材料」 ではち密な不均一組織が構築され，電気伝導度の測定から「単 一粒子混合材料」より少ない添加量で顆粒同士の接触が確認さ れ， $\mathrm{Si}_{3} \mathrm{~N}_{4}$ と TiN 顆粒及び TiN 顆粒チャネルからなる微構造 によるものと推定された。

(2)「凝集構造制御材料」の強度は添加したTiN 焼結体の 強度とほとんど同じであったが，SEPB法による勒性值では約 1.5倍の值となり，SEM 観察でも破壊経路がかなり複雑になっ ていることが確認された。 しかし，破壞勒性值についてはR カーブの測定などにより Duplex 組織を正確に評価する技術の 開発が必要である。

謝辞 本研究は工業技術院産業科学技術開発制度「シナ シーセラミックスの砟究開発」の一環として, NEDOの委託を受 けて行われたものである。

\section{文献}

1) A. Bellosi, S. Guicciardi and A. Tampieri, J. Eur. Ceram. Soc., 9, 83-89 (1992)

2）安富羲幸，中村浩介，祖父江昌久，久保 裕，セラミックス 諭文誌，97，148-54（1989）。

3）森山骞, 青木博夫, 小林義一, 鎆田喜一郎, J. Ceram. Soc. Japan, 101, 279-84 (1993)

4）森山 実, 鎌田喜一郎, 小林義一, セラミックス論文誌, 99, 286-91 (1991).

5）高橋 研，神保龍太郎，松下安男，小杉哲夫，弿協，94， 214-18 (1986)

6）山田幸良，表面技術，45，365-71（1994)。

7) K. Niihara, Seramikkusu Ronbunshi, 99, 974-82 (1991).

8）川島 健, 岡本寛己, 山本秀治, 北村 昭, セラミックス論 文誌, 99, 320-23 (1991)

9) K. M. Prewoand and J. J. Brenna, J. Mater. Sci., 15, 463-68 (1980).

10) M. P. Harmer, H. M. Chan and G. A. Miller, J. Am. Ceram. Soc., 75, 1715-28 (1992).

11) R. Landauer, J. Appl. Phys., 22, 779-84 (1952).

12) P. Dean and N. F. Bird, Math Divisional Rep., May, 61 of the National Physical Lab., Teddington, Middlesex, England (1966)

13) V. K. S. Shante and S. Kirkpatrick, Adv. Phys., 20, 325 (1971).

14) S. Kirkpatrick, Reviews of Modem Physics, 45, 574-88 (1973).

15) A. Malliaris and D. T. Turner, J. Appl. Phys., 42, 614-18 (1971)

16) K. T. Faber and A. G. Evans, Acta Metall., 31, 565-76 (1983).

17) N. P. Padture, S. J. Bennison and H. M. Chan, J. Am. Ceram. Soc., 76, 2312-20 (1993).

18) P. I. Swanson, J. Am. Ceram. Soc., 70, 279-89 (1987).

19) P. Chantikul, S. J. Bennison and B. R. Dawn, J. Am. Ceram. Soc., 73, 2419-27 (1990).

20) J. Bennison and B. R. Lawn, Acta Metall., 37, 2659-71 (1989).
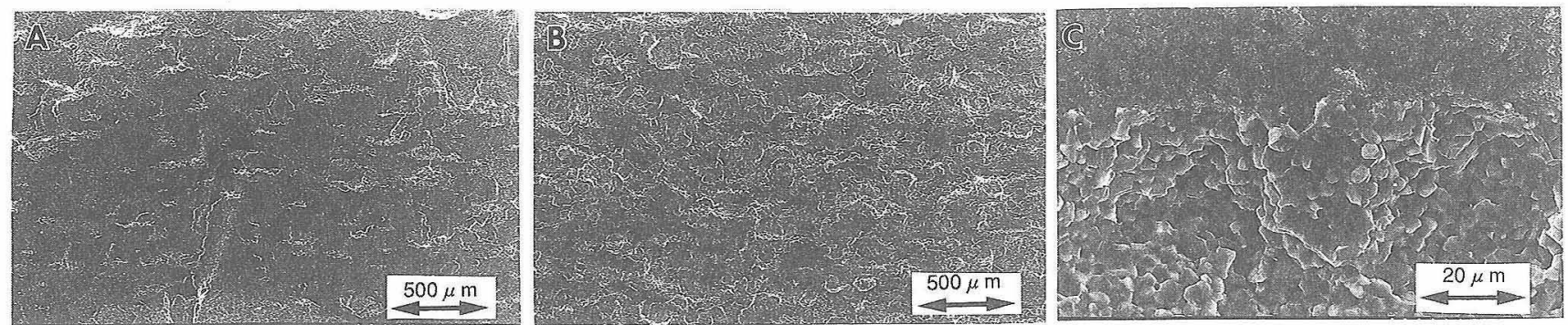

Fig. 8. SEM of fractured surfaces of agglomerates-microstructure-controlled materials.

((A) $\mathrm{TiN}=13.3 \mathrm{vol} \%$, (B) $\mathrm{TiN}=38 \mathrm{vol} \%$, (C) $\mathrm{TiN}=38$ vol\% 